http://dx.doi.org/10.1590/0104.026X2015v23n3p1035

\title{
Tempos melhores virão...
}

\section{Tempo Bom, tempo ruim: identidades, políticas e afetos. WYLLYS, Jean. \\ São Paulo: Paralela, 2014, 189 p. \\ (c) $\odot$ Esta obra está licença Creative Commons.}

Jornalista, docente, doutorando em Antropologia e filiado ao PSOL, o autor cumpre atualmente mandato de deputado federal pelo estado do Rio de Janeiro.

Sua obra está dividida em duas partes distintas: "Tempos de vida" e "Tempos de luta". Como epílogo da primeira parte, o autor utilizase dos seguintes versos de Paulo Leminski, "isso de querer/ ser exatamente aquilo/ que a gente é/ ainda vai/ nos levar além" (p. 12). Os versos dão o tom inicial e final de toda a obra, carregada de emoção, afeto e, sobretudo, realidade; a sua própria vida.

Os capítulos são em formato de crônicas mas culminam em uma autobiografia crítica. Na sequência em que são apresentados, adquirem a seguinte ordem: "Conhecer a vida"; "Ventre da mãe"; "Animal político"; "Questão de Gênero"; "Oriente-se rapaz"; "As palavras do gueto"; "Fé no que virá"; "Dias mal-ditos"; "Falar às massas"; "O desejo de representar"; "Armar-se em palavras"; "O jogo do adversário"; "Consumir a cidadania"; "Lado esquerdo"; "O lugar do armário"; "Salve Jorge" e "Santo ou orixá".

Na primeira crônica: "Conhecer a vida", o autor faz um breve relato de como foi difícil a sua infância e conclui que sua vida foi sempre uma luta. Com pouco mais de um ano, lutou contra a desnutrição e desidratação. Sua família, seu pai e sua mãe, pediam auxílio a terceiros, tendo passado seus primeiros anos de vida abaixo da linha da pobreza, na mais absoluta miséria. la para a escola com o irmão, sem nada no estômago. Aos dez anos estudava em um turno e vendia algodão-doce no outro, repassando todo o dinheiro da venda para a mãe. "Apesar das dificuldades tive uma infância alegre, típica de menino do interior: brincava na rua, subia em árvore e soltava papagaio" (p. 15). Relata que, mesmo em meio a tantas adversidades, possui "[...] algumas lembranças boas, de um tempo em que a violência ainda não havia chegado às periferias" (p. 15) e considera-se uma "exceção", utilizou-se das ferramentas da leitura, da escola e da educação para não cair nas armadilhas das drogas e no mundo do crime, que tem cooptado crianças e adolescentes dos grandes centros e periferias.

Seguiu lutando pela sua sobrevivência e de sua família. O envolvimento com a lgreja deuIhe maiores oportunidades de estudo e emprego, tendo sido menor-aprendiz da Caixa Econômica. Conseguiu por mérito estudar em um ótimo colégio na região metropolitana de Salvador. Trabalhou como programador, em um tempo em que a informática ainda era para poucos. Cursou jornalismo na Universidade Federal da Bahia. Foi repórter e professor universitário após ter concluído o mestrado em estudos culturais e literatura. Trabalhou em projetos sociais com a "proposta de uma educação através da mídia" (p. 17), para que populações carentes de 
Salvador "[...] tivessem acesso à cidadania e à justiça" (p. 17). Após mudar-se para o Rio de Janeiro, seguiu na área de comunicação como docente. Atualmente faz doutorado em Antropologia do Consumo na Universidade Federa Fluminense e representa $O$ estado do Rio de Janeiro no Congresso Nacional como deputado. Seu mandato está a serviço das minorias civis e da luta pelo respeito à dignidade humana.

A questão de gênero se fez presente na sua vida desde criança. Apesar de subir em árvores e postes e empinar pipa, não gostava de futebol como a maioria dos meninos e tinha preferência pelas brincadeiras de meninas: "adorava as atividades das meninas porque elas tinham tudo a ver com meu gosto por música, formas, cores e texturas, e com minha disposição com o afeto, o toque e a comunhão"; de alguma forma, achava as atividades masculinas brutas e violentas.

Reconheceu-se com uma orientação homossexual no princípio da puberdade. Sentiu-se atraído por homens aos quinze anos e, ao completar dezesseis, resolveu assumir sua homossexualidade. Seu irmão e sua irmã o apoiaram. Sua mãe também, não sem antes chorar e exprimir o desejo da maioria das mães: "que eu fosse heterossexual" (p. 26). Relata que sua mãe não estava enganada: "num país preconceituoso como o nosso, há uma dificuldade maior para os homossexuais alcançarem a felicidade; todavia, parece-me mais difícil viver na vergonha, fechado no armário". Ao explicar para a sua mãe que era um homem honrado e que, independentemente de sua orientação sexual, ainda lhe daria muito orgulho, a confiança dela aumentou $e$ transferiu-Ihe a responsabilidade que deveria se de seu pai - a função de "homem da família". Eis um paradoxo.

Outro aspecto marcante da obra refere-se à identidade religiosa: "Tenho uma religiosidade, não tenho uma religião" (p. 30). Conheceu o engajamento político através da fé católica na infância, mas, ao entrar na adolescência, com a presença dos afetos e dos desejos, afastou-se da igreja, pois queria saber por que a Igreja não tratava da questão da homossexualidade. Ao questionar a lgreja, foi considerado "sem fé" pelo Bispo Jaime, e desde então flertou com o ateísmo. Percebendo-se incapaz de ser ateu, não conseguindo viver sem uma crença, aproximouse das religiões de matriz africana - o candomblé. Coloca-se bravamente contra "a perseguição sistemática que sofrem até hoje os adeptos da umbanda e do candomblé por parte de fundamentalistas e fanáticos cristãos, que chegam a invadir terreiros e usar de violência física contra ialorixás e babalorixás". Afirma que o cristianismo no qual foi formado valoriza a vida humana, prega o respeito aos diferentes e se dedica à proteção dos fracos e oprimidos. Utiliza-se da máxima bíblica de Jesus de Nazaré: "Eu vim para que todos tenham vida; que todos tenham vida plenamente". Afirma que a liberdade de crença, utilizando-se da máxima de Cristo, "não deve ser um direito só dos cristãos" (p. 30-31).

Posiciona-se também a respeito da ditadura militar no Brasil, pois nasceu no ano de 1974, sob a presidência do general Ernesto Geisel. Declarase contrário a todas as práticas ditatoriais e utilizase da seguinte expressão: "dias mal-ditos", ao falar da ditadura no Brasil. Destaca um ponto importante, que é o fato da atual presidente do Brasil, Dilma Rousseff, ter sido vítima direta dos crimes da ditadura militar e agente de resistência ao terrorismo de Estado praticado naqueles anos. Declara-se favorável à Comissão da Verdade, mas, para garantir lisura, ajudou a constituir uma Subcomissão Parlamentar da Memória, Verdade e Justiça, coordenada pela deputada Luiza Erundina. Alude que "não podemos reconstruir tudo, mas a utopia de tudo saber a respeito daquelas páginas infelizes de nossa história deve servir como um programa, um horizonte e uma advertência para o futuro" (p. 37).

Na crônica "Falar às massas", faz uma crítica, "apesar de uma recente abertura das novelas a representações novas e produtivas da homossexualidade, a regra tem sido o recurso a estereótipos como forma de reafirmar e reproduzir as normas que sustentam a superioridade dos heterossexuais, bem como seus privilégios" (p. 39). Se, por um lado, as novelas produzem estereótipos por outro, provoca a sociedade para no mínimo discutir sobre essa minoria e seus impactos nas relações socioculturais. "Há quem diga que as tramas são abstrações", mas elas ajudam a produzir o insulto ou a injúria: "da piada sobre "bicha" até suas manifestações mais graves, que é o assassinato com requintes de crueldade" (p. 41). Em geral "os dramaturgos da Rede Globo têm tentado criar personagens que, de forma tímida ou não, colocam em cena a diversidade dos comportamentos homossexuais" (p. 43). Conclui destacando que não se pode ignorar o papel da mídia como um elemento de combate e debate sobre a diversidade de orientação sexual e compromisso com a construção de uma sociedade caracterizada pelo respeito à dignidade humana.

O desejo de representar surge por sempre ter acreditado que, "como cidadãos, todos nós 
podemos intervir na vida política. Esse é o cerne da democracia e significa pensar a sociedade e participar do debate social como cidadão e trabalhador" (p. 48). Identificou-se com o PSOL, "por sua defesa das liberdades e garantias individuais, por sua luta pelos direitos fundamentais dos indivíduos de ir e vir, de expressar sua religiosidade e de afirmar sua sexualidade" (49). Decidiu candidatar-se a deputado federal pelo estado do Rio de Janeiro, onde vive desde 2005.

Em "amar-se em palavras", declara ter aversão à violência física e que nunca se envolveu em pancadaria, por qualquer motivo. Nas bataIhas políticas e legislativas, seu arsenal é composto de "palavras", aquelas escritas nos projetos de lei. Cita o exemplo da simples troca do vocábulo "aidético" pela expressão respeitosa "pessoa com HIV". Sempre prefere usar palavras como armas, que as armas propriamente ditas. Sintetiza que "o amor ao outro - a ética por excelência - é o que pode manter qualquer conflito no âmbito das palavras, de modo que não resulte na $\mathrm{Paz}$ dos Cemitérios" (p. 51).

"Tempos de luta", título da segunda parte, inicia-se com a frase de Michel Foucault em uma entrevista intitulada: 'Sexo, poder e a políica de identidade', "nós devemos compreender que, com os nossos desejos, por meio deles, instauramse novas formas de relações, novas formas de amor e novas formas de criação" (p. 71).

A primeira crônica: "As lições de Stonewall", faz um balanço da história de luta dessa minoria (LGBT) que, ao reivindicar seus direitos ou procurar influir na organização de relações que a oprimem, são desclassificadas em suas lutas e movimentos, sendo acusadas de implantar uma "ditadura gay". Ocorreu em Nova York uma série de conflitos violentos entre homossexuais e a polícia, no ano de 1969, em um bar chamado Stonewall, marcando o início de uma luta que inspira até hoje as paradas LGBT em todo o mundo.

O texto seguinte trata do conceito da homofobia, que é o nome que se dá ao medo, aversão ou ódio irracional que algumas pessoas nutrem em relação aos LGBT. A homofobia, uma vez disseminada em nossa sociedade, vitima milhares de homossexuais diariamente.

Nessa segunda parte, outros assuntos também polêmicos que afligem a sociedade brasileira, não menos importantes que a homofobia, são abordados: casamento igualitário e criminalização da homofobia, liberdade de expressão, maioridade penal, reforma política e eleitoral retorno do fascismo, questão do HIV, manifestações populares de junho de 2013, drogas, ação policial, comissão da verdade sobre os anos da ditadura militar, a Igreja Católica depois do Papa Francisco, profissionalização da prostituição, cura gay, cultura digital do ódio, papel da mídia (o dilúvio de (des)informação), e o fundamentalismo; sempre na perspectiva dos direitos humanos.

Antes de concluir a abordagem Wyllyana, torna-se importante destacar a frustração que o autor demonstra com relação aos homossexuais, que não conseguem aceitar-se como tal e vivem escondidos de si e da sociedade. Segundo Wyllys, seriam estes os responsáveis pelo enfraquecimento das lutas dessa minoria civil - por liberdades e igualdades - frente ao Estado brasileiro.

O autor conclui a obra colocando o "pensamento" como sendo o fundamento singular do ser humano, que o faz distinto dos demais seres vivos, e recorre seu próprio passado, como já foi dito, destacando que sua infância e trajetória para chegar onde está hoje não foram nada fáceis; viveu por muito tempo abaixo da linha da pobreza, tendo que começar a trabalhar aos dez anos de idade; por ser homossexual, diferente da norma padrão (heterossexual), conheceu muito cedo o insulto e as humilhações públicas. Mas ressalta que todos esses fatos, toda essa experiência, deram-lhe condições para elaborar seus primeiros pensamentos críticos; como exemplo, cita a grande filósofa alemã Hannah Arendt, naquilo que ela chama de "vida com pensamento". Termina por destacar o papel da educação, o dever do Estado em ofertá-la com qualidade e com o objetivo de promover a autonomia do indivíduo, para que possa gozar plenamente de sua cidadania, que não é apenas utopia, mas que considera possível de ser concretizada.

Se fizermos uma analogia entre o título do livro: Tempo bom, tempo ruim, e a divisão po partes: "Tempos de vida" e "Tempos de luta", podemos supor que tempo bom corresponde aos tempos de miséria, fome e dificuldades, mas brincando como criança e recebendo afeto de sua família, quando ainda não havia sido apresentado ao preconceito; e tempo ruim se refere aos tempos de luta, das dificuldades de transpor as barreiras do preconceito e lutar contra forças poderosas enraizadas em nossa sociedade e em nossa política. O que para muitos seria pior passar fome física, para o autor, o ruim é não saciar a sede de justiça social e vivenciar a violação de direitos humanos.

Apesar de a obra aparentemente ser considerada de valor não acadêmico, está embasada em discussões do interesse das ciências sociais e da ciência políitica, em específico, ao tratar de assuntos da maior relevância: desigualdades sociais, educação, saúde, segurança, 
cidadania e direitos da pessoa humana. O autor sabiamente escolhe sua própria história de vida para dar maior significado e realismo aos temas abordados, principalmente quando conta a sua própria história de pobreza, mas também quando se assume parte de uma minoria (homossexual). Atualmente a minoria que é mais atacada pela sociedade civil e política (fundamentalistas), seja de forma simbólica, seja pela violência física, elevando os altos índices de homicídios e violência no Brasil.

Keula Andrade Rodrigues Centro Universitário Unieuro

1038 Estudos Feministas, Florianópolis, 23(3): 1023-1044, setembro-dezembro/2015 